\title{
The Implementation of Marketing Public Relations Strategy by the FF Luxury Watch Store on the Jakarta Based Customers
}

\author{
Abdul Rahman, Vania Utamie Subiakto, Susi Susanti, Djaswahadi Purwoputro \\ Faculty of Communication \\ Mercu Buana University and Brain Group Human Resources Development Institute Indonesia
}

\begin{abstract}
Marketing Public Relations is implemented among the customers with reference to the following strategies: (1) push strategy; (2) pull strategy; and (3) pass strategy. Pull Strategy refers to the strategy that might be implemented for stimulating a successful sale by means of certain tactics directed toward drawing the customers. Then, Pass Strategy refers to the strategy that might be implemented by means of engagement with social activities, social responsibilities, and charities. One of the ways that might be pursued under the initiative of Pass Strategy is being the sponsor of fundraising events with the Indonesian Cancer Foundation, with the orphanages, and other types of events. Furthermore, Push Strategy deals with the Marketing Public Relations Program and serves as the effort for stimulating the sale and providing the values or the satisfaction to the customers who have purchased the product of the given company. Customer satisfaction is indeed the result of customer evaluation toward the chosen alternatives, which has at least resulted in the same expectation or which has even exceeded the expectation of the customer. On the contrary, uncertainty appears when the results that have been attained do not meet the expectation of the given customer.
\end{abstract}

Keyword:- Marketing Public Relations, Pull Strategy, Push Strategy, Pass Strategy.

\section{INTRODUCTION}

People of Jakarta Special Capitol live in five different administrative regions and one administrative regency namely the Administrative Region of Central Jakarta, the Administrative Region of North Jakarta, the Administrative Region of West Jakarta, the Administrative Region of South Jakarta, the Administrative Region of East Jakarta, and the Administrative Region of Seribu Island (Dinas Kebersihan, 2018, p.1).In these administrative regions of Jakarta, there are a lot of business actors who offer their products, namely watch, to the customers. These business actors or the socalled watch sellers offer various products, from the trendy one up to the luxurious one, which might fit into the interest of the customers.
With regards to the above elaboration, nowadays many problems have occurred in the aspects of business. One of these problems is the increasingly intense level of competition among the watch brands, which eventually results in the competition for the novel innovations both in terms of product and in terms of marketing. All of these innovations are pursued in order to boost the sale and the income of the company. With reference to pursuance toward these innovations, through the effective management of marketing public relations, especially on the items that belong to the tertiary goods such as watch, it is expected that the population of prospective customers might be improved. At the same time, marketing activities might serve as the benchmark or the reference of a company in identifying the types of the customer needs. By doing so, a company might develop the product, the price, and the service and also promote these aspects in order to cater the customer needs. In turn, the fulfilment of the customer needs results in the improvement of the company income.

Marketing activities contain communication process that should be undergone within the marketing process from the sellers to the buyers. The communication itself refers to the process in which the thoughts and the understanding are shared among the individuals or between organizations and individuals (Vania, 2019, p.34). Therefore, marketing activities can serve as the benchmark or the reference for identifying the customer needs. Consequently, a company might develop the product, the price, and the service and might also promote the three aspects in order to meet the customer needs and eventually improve the income.

In performing the sale, it is suggested that a businessman should have public relations that should be understood and be performed within the sale process and the statement also applies to the FF Luxury Watch Store. Therefore, there are several activities that should be performed by an individual, a group of individuals, or an institution in order to provide assistance and convenience under the objective of meeting certain goals. Specific to the context of the study, the FF Luxury Watch Store meets the customer needs in this regard by providing information around the watch the customers want to find the watch that suits their needs most (Jamil, 2018, p.153). 
In order to improve the continuous sale, many companies define synergic strategy managements and one of them is the marketing public relations strategy. Such strategy is define because companies view that the management of marketing public relations strategy might serve as a marketing communication tool. The marketing public relations strategy itself is a combination of corporate public relations and marketing public relations.

In implementing the management of marketing public relations strategy, there are three important strategies that might be taken namely: (1) push strategy; (2) pull strategy; and (3) pass strategy. The three strategies should be implemented in order to achieve the goal of a company: to improve the income / the earnings of the company. In the modern era, the role of marketing public relations become highly important because the good will of a company is the material or the factor that has been highly considered by the customers as the customers decide which product that they want to purchase.

It is inevitable that public opinion on a product still highly influences the sale of the product; therefore, there should be the division / the unit of a company that is considered capable to shape positive response from the public and stir the public opinion in accordance to the expectation of the company. In this regard, the researchers are interested to study the management of public relations strategy that have been implemented by a shop that markets the tertiary goods. As a result, the recent study will focus on the watch, which belongs to the tertiary goods, and in conducting the study the researchers have selected Ms. Susanti as the object of the study. In sum, the researchers will study the management of marketing public relations strategy that has been implemented by the FF Luxury Watch in marketing the luxurious watch products to the customers who live in Jakarta.

The study itself will be elaborated and focused further into the following problem formulation: "How does the FF Luxury Watch Store implement the management of marketing public relations strategy in Jakarta?" Within the implementation of the management of marketing public relations strategy by the FF Luxury Watch Jakarta, it is believed that through the push strategy the Store will boost the purchase and the provision of satisfactory values or satisfaction among the customers, through the pull strategy the Store will draw the interest of the customers at all cost in order to achieve the company objective and boost the sale of both the product and service, and eventually through the pass strategy the Store will influence the creation of the public image toward the problems that have been related to the social conditions occurred within the Store.

\section{LITERATURE REVIEW}

\section{A. Communication Theory}

The term communication is derived from the Latin word communication, which refers to notification, provision of several parts, and a trade of messages between the speakers and the listeners in taking participations. Its adjective form, communis, bears the characteristics of communalities. On the contrary, its verb, communicare, means to have dialogue, to have negotiation, or to have discussion among individuals (Arifin, 2015, p.82).

Communication itself, then, might be defined as a process of transmitting message from the communicator to the communicant by means of media that might trigger certain effect. Then, the communication process itself does not stop at the effect; instead, the communication process extends to other aspect known as feedback. In feedback, the response from the communicant is sent to the communicator in order to identify whether the preliminary message from the communicator is well accepted by the communicant or not (Mulyana, 2001, p.41).

Therefore, communication becomes important since every individual communicates from one to another and, not to mention, the objective of establishing communication is to send messages to the other people and to gain feedback from the communicators. According to Fajar, (2009, pp.1011 , there are four functions of communication namely:

\section{Social Communication}

Communication as a social function aims at establishing the self-concept. Individuals who do not establish communication with others might be lost because they are unable to establish themselves within an environment.

\section{Expressive Communication}

Communication as an expressive function serves as a tool for conveying the feelings that an individual has. The presence of these feelings might be challenged through music, painting, or dance.

\section{Ritual Communication}

Communication as a ritual function is performed collectively. A community usually perform different types of rite throughout the year and throughout the life of the community members. The people who establish this kind of communication are known to be the anthropologists.

\section{Instrumental Communication}

Communication as an instrumental function serves as an instrument for achieving the individual objectives and the employment objectives and also the short-term objectives and the long-term objectives. 
In relation to the above elaboration, effect refers to the difference among what an individual thinks, perceives, and performs before and after the retrieval of the message from a communicator. According to Vardiansyah (2004, p.110), the communication effect is divided into three categories namely:

\section{Cognitive Effect}

Cognitive effect refers to the effect that appears for the very first time and aims at delivering the message so that the communicant will understand the message that has been retrieved. Then, this message might be changes of perception or changes of opinion.

\section{Affective Effect}

Affective effect refers to the effect that impacts the feeling of an individual. The affective effect of communication usually takes place after a communicant has read the message from a communicator.

\section{Conative Effect}

Conative effect refers to the effect that impacts that appear after the mass or the listeners identify and perceive the content of the message that has been retrieved. At the next level, the mass or the listeners will take certain actions, both the physical ones and the non-physical ones, based on the content of the message.

\section{B. Public Relations}

Harlow states that public relations has peculiar functions of management because a public relations officer plays the role of establishing and maintaining the communication path, inciting understanding, establishing cooperation between the organization and the public, involving the issues management, assisting management in informing and responding to the public opinion, and also defining and emphasizing the management responsibility for serving the public interest. In addition, a public relations officer should assist the management to always attend to and benefit changes effectively with regards to the public of the organization within a company. Furthermore, a public relations officer serves as an early warning system in order to prevent the negative tendency, to use the results of several healthy studies, and to hold the communication ethics as the tool in the conduct of the duty (Frank, 2003, p.9).

Public relation is considered as a function of leadership and a function of management especially in the achievement of the company objectives, in the assistance of the company philosophy definition, and in the facilitation of organizational changes upon the management policy. A public relations officer conducts his or her duty through the communication to each stakeholder, namely the internal stakeholder and the external stakeholder. At the same time, the public relations officer conducts his or her duty in order to develop the positive relationship with each stakeholder so that a consistency between the organizational objectives and the public expectations might be created. Last but not the least, a public relations officer should also develop, implement, and evaluate the programs of the organizational policies that promote the trade of influence and understanding between the organization constitution and the public (Lattimore, 2010, p.4).

\section{Marketing Public Relations}

The increasingly intense business competition in today's era has resulted in the increasingly complex activities of public relations within any company. Public relations department nowadays has been demanded to be able to pursue innovations through activities that might improve the competitive edge of the company. Indeed, numerous activities have been performed, starting from holding numerous promotions, taking participation in the developmental programs initiated by the government, and until improving and maintaining the impression of the brand. All of these situations have made the duty of a public relations officer increasingly complex within the efforts to maintain and improve the competitive edge of the company. Due to these increasingly progressive activities, the term marketing public relations made its first appearance.

As having been previously explained, a marketing public relations officer has very complex duty and responsibility in a company. If a public relation officer within a company represents the overall brand of the company in order to shape the positive impression before the public, then a marketing public relations officer has more specific duty and responsibility namely to bring his or her company closer to the customers by means of numerous activities. Then, from the evaluation toward the activities that have been performed, a company might define which strategy that should be implemented. In other words, the marketing public relations aims at convincing the customers about the brand of a product that the company has offered and, at the same time, forging good relationship with the customers through marketing communication.

Harris has coined the term marketing public relations and in his opinion marketing public relations refers to the program planning, implementation, and evaluation which aims at stimulating purchase by means of costumer satisfaction. Similarly, Ruslan (2007, p.245) states that marketing public relations refers to the combination between the program implementation and the marketing strategy by means of public relations work program activities as the effort of expanding the marketing initiatives and achieving the customer satisfaction. The customer satisfaction itself might be triggered by using reliable information and communication with regards to the impression that a company has displayed. In this regard, the reliable information and communication should contain the products that have been sold in accordance with the needs, the desires, the attentions, and the interests of the customers (Alifahmi, 1994, p.30).

The increasingly advanced market conditions have not been accompanied by the product marketing plan strategy. As a result, it becomes more difficult for companies to achieve their objectives. Due to this situation, companies should devise, develop, and deliver messages that increase their credibility and their positive impression in front of the public. In line with this initiative, the presence of the 
marketing public relations does not only deliver the credibility-increasing messages but also communicate the company ideas so that the customer behaviours might be changed and directed to the purchase. According to Ruslan (2001, p.246), there are four types of marketing public relations objective namely:

1. Growing and developing the positive impression of a company in front of the stakeholders, the public, and the customers

2. Fostering the achievement of mutual understanding between the targeted customers and the company

3. Developing the marketing function by means of public relations

4. Supporting the marketing mix

Furthermore, with regards to the marketing public relations strategy, Rosady (2010, p.246) has classified the marketing public relations strategy into three categories as follows.

\section{Push Strategy}

In push strategy, the public relations enable the stimulation or the promotion of a purchase and provide added value or satisfaction for the customers who have used or consumer the product of a company.

\section{Pull Strategy}

In pull strategy, the public relations have the potentials to bear tactics for drawing attention of the potential customers by means of all necessary means in order to achieve the company objectives and improve the sale of both the company product and service.

\section{Pass Strategy}

In pass strategy, the public relations afford the creation of public image by holding numerous events and taking participation in social activities as part of the corporate social responsibility initiatives. In other words, the use of pass strategy displays the company concern toward the problems that take place in the surrounding community.

\section{METHOD}

Within the study, the constructivism paradigm had been adopted. Then, during the study the researchers had the freedom to implement certain research method. In relation to the previous statement, the research method that had been implemented was the descriptive qualitative method because the researchers strove at uncovering the problems as they were. Not to mention, the nature of the descriptive qualitative research method has emphasized originality in any type of condition and, therefore, the results of such research method has had more emphasis on the meaning. The problems were related to the implementation of the public relations marketing strategy by the FF Luxury Watch to the customers in Jakarta.

The subject that had been selected for the study was the one who understood well the marketing public relations strategy that the FF Luxury Watch Store had implemented. Consequently, the researchers should involve the Owner, the Marketing Management, the Sale Supervisor, and the Field
Marketing Staff, and the customers of FF Luxury Watch Store into an in-depth interview. The aim of conducting the in-depth interview was to gather information that might be relevant to the title of the study namely "The Implementation of Marketing Public Relations Strategy by the FF Luxury Watch Store on the Jakarta-Based Customers." In addition to the in-depth interview, the necessary data were also gathered by means of observation and documentation study. After the data had been completely gathered, the data were analysed by using the qualitative approach. The data validity itself was inspected by using triangulation, observation persistence, and peer assessment. Specific to the context of the study, the researchers would compare the observation data and the interview results.

\section{RESULTS AND DISCUSSIONS}

In business management, there are strategies of marketing public relations that should be implemented and this also applies to the FF Luxury Watch Store. Then, the activities that have been devised within the strategies of marketing public relations should be useful for internalizing the awareness and the knowledge toward information delivery, product marketing, and good relationship establishment and maintenance between the FF Luxury Watch Store and the customers. Thereby, good relationship might be created in building trust and interest among the customers. According to Harris, marketing public relations might be defined as the process of planning and evaluating the programs with the aim at stimulating purchase and customer interest toward the products that have been marketed.

These activities should be performed through communication activities by providing credible information that might link the company, the products that have been marketed, and the targeted or the potential customers. In this regard, the marketing public relations does not only focus on the sale but also on the delivery of reliable information and positive impression that the company has created through the programs of marketing public relations. In doing so, the management of marketing public relations strategy among the customers should refer to the theory that has been proposed by Harris in Ruslan (2010, p.246), which state that in general the concept of marketing public relations consists of three strategies namely push strategy, pull strategy, and pass strategy (Ruslan, 2010, p.210).

\section{A. Push Strategy Content in Attracting Customers' Interests}

The programs of marketing public relations should be implemented in order to stimulate purchase and provide values of satisfaction altogether for the customers who have purchased the products of the FF Luxury Watch Store. Customer satisfaction results from the evaluation that the customers have made. In the case of satisfaction, the alternative that has been chosen provides the results that meet or even exceed the customer expectation; on the contrary, in the case of uncertainty, the alternative that has been chosen does not provide the results that meet the customer satisfaction or, in fact the alternative that has been 
chosen falls below the level of the customer satisfaction (Engel, 1990).

According to Kotler (1994), customer satisfaction refers to the level of an individual's perception after the individual compares the perceived performance and the expected performance. Customer satisfaction holds very vital role for a company because the creation of customer satisfaction will indirectly create harmonious relationship between the company and the customers. In turn, the harmonious relationship might be turned into a recommendation from one customer to another.

In general, customer satisfaction is resulted from the quality of both the product and the service that have been offered to the customers by the company. Therefore, maintaining the customer satisfaction holds an important role since the customer satisfaction will result in the customer loyalty within the purchase toward the product of the company. Specific to the context of the study, the customer satisfaction is resulted from several activities that the FF Luxury Watch Store has performed for the customers and one of such activities is attaining the customer satisfaction by implementing the strategies of marketing public relations. These activities might be different from one company to another depending on the strategies that have been implemented. However, the presence of marketing public relations activities might serve as one of the approaches that a company should pursue in order to target the potential customers. As an approach, the marketing public relations might be implemented by lobbying the potential customers. The act of lobbying the potential customers is considered as part of the push strategy that a company can implemented and this statement also applies to the FF Luxury Watch Store.

The lobby strategy is carried out by the FF Luxury Watch Store through the pursuance of in-depth approach to the potential customers. Through the in-depth approach, the Store is able to gain deeper understanding toward the customer characteristics; for example, the Store is able to identify the customer characteristics by viewing the customer motivation in purchasing a watch. The customer motivation itself might be defined as the internal situation of an individual that encourages individual desires to perform activities in order to achieve certain objectives or goals (Nugroho, 2003).

The motivation of an individual encourages him or her to be more focused in directing the behaviours toward achieving the desired goals. Motivation might appear from the needs that the customers desire and the needs alone appear because the customers perceive the state of tension between the expected perception and the actual perception. The perceived needs encourage an individual to take certain actions in order to meet these needs and it is from this point that the needs come to the surface (Sumarwan, 2002). The success of a lobby is defined by how great the knowledge that the Store has in understanding the types of the motivations among the potential customers and the success within the lobby will deliver the Store to achieve the goals, namely the creation of sale transactions.

In the context of marketing, motivation is divided into two categories namely the rational motivation and the motivation. The rational motivation refers to the purchase that has been based on the facts that have been prominent among the customers and become the attributes of the functional products and the objective products, for example: (1) product quality; (2) product price; (3) product availability; (4) product usefulness and efficiency; and (5) customer rationale. On the contrary, the emotional motivation refers to the purchase that has been based on the perception and the happiness that the senses have caught. For instance, a customer affords the product in order to raise his or her social status before the public because the product has been manufactured by the famous brand. This customer would like to show his or her economic status to the public despite the fact that the status is only subjective or symbolic. In sum, the presence of the decision in purchasing a product is influenced by two motivations namely the rational motivation and the emotional motivation (Sigit, 2002).

After a seller has identified the customer motivation, such as the needs to purchase luxurious watch in order to show the lifestyle, to perform the daily routines, or even to invest, the seller might suggest the potential customers about the type of the luxurious watch that might be worn. The luxurious watch itself might be adjusted to the motive or the needs of the customers. Afterward, the seller might provide several alternatives that might be suitable for the potential customers based on the preliminary motivation, which encourages the potential customers to afford the luxurious watch.

Within the implementation of the lobby strategy, information and knowledge might be provided to the potential customers with regards to the strengths and the weaknesses of each product as a customer has made his or her purchase decision. According to the observation of the researchers, the FF Luxury Watch Store has successfully implemented the lobby strategy because the Store has been able to deliver both of the information and the knowledge with regards to the luxurious watches that the customers demand. In this regard, the implementation of the FF Luxury Watch Store bears certain motives based on the interview results. One of these motives is to encourage the interest of the customers to purchase the products that the Store has offered.

The presence of the push strategy provides certain advantage for the Store. The advantage that has been attained by the company from the implementation of the push strategy is that the FF Luxury Watch Store has sold the product to the customers by delivering preliminary information to the potential customers and sealing the purchase transaction of the watch among these customers. The presence of the goals from the push strategy results in the purchase transaction that has been sealed by the provision of product knowledge to the potential customers. In other words, it might be concluded that the purchase 
transaction has taken place due to the lobby toward the potential customers by the salespersons of the Store.

\section{B. Pull Strategy Content in Attracting Customers' Interests}

The pull strategy has been implemented in order to stimulate the success of the sale by using the tactics of drawing the customer interest. This strategy might be implemented by numerous ways in order to achieve the company objective and in to increase the sale of the products that the company has offered. The main objective of the pull strategy is to establish long-term relationship between the Store and the customers; in this regard, it might be defined that the main objective of the pull strategy is to establish the customer loyalty to the sellers.

Pull strategy refers to the way for sealing purchase transaction. The pull strategy might be implemented through two ways. The first way is drawing the customer interest by presenting the brand of a product in order to create a strong purchase desire. Then, the second way is ensuring the product availability within the sale process. Through the marketing strategy that draws the business interest, the product or the service that has been offered by a store might be positioned into the path of the potential customers.

Furthermore, the pull strategy might be defined as an effort that has been pursued in order to draw the customer interest by means of numerous marketing activities such as promotion, advertisement, and product innovation with excellent customer service. According to Kotler (2007, p.369), pull strategy might also be defined as an activity of sale promotion to the final customers by means of advertisement and customer promotion in order to look for the intermediary within the order of the products necessary for the customers to the producers. In this regard, the FF Luxury Watch Store has performed the marketing public relations activities by giving discounts to the customers who take participation in numerous events that are related to the products that have been offered. The example of those activities are free polish facility by purchasing the products sold in the FF Luxury Watch Store and free VVIP-entry bonus. The complete activities of FF Luxury Watch Store will be elaborated further in the following sub-sections.

\section{$>$ Giving Discounts to Customers}

Giving discount is an activity that has been routinely implemented by the FF Luxury Watch Store. The discount is given whenever the customers purchase the watch accessories such as strap, pouch, and alike in order to draw the customer interest to stop and shop in the story. The implementation of this strategy has been considered successful because the customers are interested to shop at the Store due to the discounts. In higher degree, the customers might even purchase the watches and sell them to the other customers. Indeed, most of the customers in the FF Luxury Watch Store are categorized as either reseller or distributor.

\section{Taking Participation in Numerous Event}

The FF Luxury Watch Store also performs other activities in order to draw the customer interest. One of these activities is taking participation in numerous events.
These events are related to the products that have been offered by the Store such as the launch of the latest super car model. In the launch of the latest super car model, the FF Luxury Watch Store has established partnership with the supplier of the supercar such as Prestige Indonesia. Taking participation in numerous events is indirectly useful for expanding the list of the potential customers who will purchase the watch that has been offered by the Store. Not to mention, the customers who like collecting the luxurious cars usually also like collecting the luxurious watches. As a result, these potential customers might be lobbied to purchase the luxurious watches that the FF Luxury Watch Store has offered.

\section{$>$ Providing Free-Polish Service}

The FF Luxury Watch Store provides the free-polish facility for each purchase. The presence of the free-polish facility is indeed an effective strategy that might draw the interest of the potential customers. The free-polish service is believed to cut the expensive maintenance cost of the watch. Not to mention, the free-polish service itself might be useful for creating the customer loyalty to the Store. Loyalty is an evidence that the customers will stick to certain stores and becomes the power for supporting and being positive with the company.

A company will gain several benefits if the company has loyal customers. The first benefit is that the company might cut off the marketing cost because the cost to attract new customers is higher than the cost to attract the loyal customers. Then, the second benefit is that the company might cut off the transaction cost. In this regard, the transaction cost refers to the negotiation cost, the contract cost, and the order-processing cost. These costs are incurred whenever the new customers commit a purchase. Next, the third benefit is that the company might cut off the turnover, namely the cost that has been incurred due to the lower level of customer change. Furthermore, the fourth benefit is that the company might increase the cross-sale, which will maximize the market segment of the company. Consequently, when a company wants to open a new branch the company does not have be troubled with any consideration toward the marketing strategies for the given products. The reason is that the branch has already referred to the main company which has manufactured the given products. Last but not the least, the fifth benefit is that the company might rely on the word of mouth; in this regard, the assumption is that the loyal customers are the ones who have been satisfied with the advantages of the product that they have purchased. Through the use of the word of mouth, the company might cut off the failure cost. The failure cost is incurred when there is a new customer who has not understood the overall mechanism on the product use (Griffin, 2003, p.223).

Indeed, the provision of the free-polish service has been considered successful because such a kind of service has not been found in any similar store. The high price within the polish service will automatically create the loyalty among the customers who have sealed their purchase transaction in the FF Luxury Watch Store. 


\section{Provision of Very-Very Important Person (VVIP) Member Bonus}

The implementation of Very-Very Important (VVIP) Member Bonus has been considered successful because the customers stay shopping in the FF Luxury Watch Store in order to claim the bonus. However, in order to claim this bonus, the customers should go through several stages consistently in a long term. The VVIP Member Bonus has been provided in order to appreciate the customers who have established and maintained long-term relationship with the Store. Then, the benefits that are offered in the VVIP Member Bonus are having the voucher of accommodation in the Marina Bay Sands Singapore and getting special price or discount for every purchase.

Due to these lucrative benefits, the customers of the FF Luxury Watch Store stay loyal and, in fact, stay being the VVIP Member of the Store. The presence of this strategy has completely confirmed the loyalty of the customers to the Store. Not to mention, the implementation of such pull strategy has successfully drawn the interest of the customers to purchase the products that have been offered by the FF Luxury Watch Store. Furthermore, the implementation of this strategy has supported the implementation of the other strategies that have been previously mentioned namely the provision of free-polish service, discount, and event-related participation in achieving the company goal, which has been sealing a purchase transaction. Not to mention, the objective of the pull strategy itself in this regard is to seal purchase transactions that might be attained from numerous activities that are interesting for the customers of the Store.

\section{Pass Strategy Content in Attracting Customers' Interests}

The pass strategy is implemented in order to influence or persuade the public and also to create public opinion that might be beneficial for the FF Luxury Watch Store. In addition, the pass strategy might be implemented as an effort of creating better company image and this company image itself might appear from numerous activities or events that have been displayed in order to communicate the message to the targeted audience so that the targeted audience will show concern toward the social conditions and take participation in the social activities.

The pass strategy has been implemented through numerous social activities or social responsibilities and also through the concerns toward the social condition-related problem. Specific to the context of the study, the FF Luxury Watch Store once became the sponsor for the charity event held by the Indonesian Cancer Foundation (came the sponsor for the charity event held by the Indonesian Cancer Foundation (YKI, Yayasan Kanker Indonesia), in the charity event for the orphans, and also in the Merdeka Run, which is held annually for commemorating the Independence Day of the Republic of Indonesia.

Furthermore, the pass strategy that the FF Luxury Watch Store has implemented might be elaborated as follows.

\section{$>$ Fund Gathering Event for the Indonesian Cancer Foundation}

The objective of holding the fund-gathering event with the Indonesian Cancer Foundation is that the FF Luxury Watch Store would like to deliver positive impression before the public so that the public shows the empathy to shop at the Store. The presence of the positive impression before the public has indirectly shaped the customer loyalty to keep shopping at the FF Luxury Store and, at the same time, the positive impression might improve the company impression. The reason is that the opinion that has been developed within the public will shape the company impression before the customers and shape the reputation for the company itself.

Therefore, in conducting the activities for developing cooperation with other companies, the social activities have become the main alternative and this statement has been completely confirmed by the cooperation between the FF Luxury Watch Store and the Indonesian Cancer Foundation for the fund-gathering events. As a result, by purchasing the products in the FF Luxury Store the customers will also donate some of their money to the Foundation and the money that has been collected later will be used for the greater interest of the cancer patients. Such cooperation itself has become the character that discerns the company from its competitors. In turn, this kind of activity has become a peculiar characteristic for the company since not all companies hold social activities that display positive impact and deliver innovation to the company. This innovation is usually in the form of marketing strategy that has been implemented. Last but not the least, the presence of such social activity might support the assumption that the customers will stay loyal to the Store since the social activity indirectly takes participation in the fund-gathering event.

\section{Fund Gathering Events for the Orphan}

Another implementation of the pass strategy is taking participation in gathering the fund for the orphans. The customers who take participation in the fund-gathering event for the orphans will indirectly take participation within the establishment of the positive image before the public. The positive image is useful for influencing the public view toward the FF Luxury Watch Store and will provide significant assistance in achieving the goal of the sale process namely the occurrence of luxurious watch purchase transaction.

At the same time, this activity is able to draw the interest of the customers to take participation in other social activities held by the Store. By taking participation into such charity events, the work enthusiasm among the employees will increase and the sense of pride among the customers will be created. The participation of the customers itself in this kind of activity has been another strategy that the company has implemented in order that the employees become more enthusiastic in performing their job for the sake of the future company's advancement. Off the record, the FF Luxury Watch Store often holds charity events in the surrounding neighbourhood in order to strengthen the 
relationship among the employees (Qerja Empowering Your Career, accessed from https://www.qerja.com/journal/view/3734-pentingnya-

kegiatan-sosialre-bagi-perusahaan/).

\section{Taking Participation in the Merdeka Run}

Another participation by the FF Luxury Watch Store is becoming the annual sponsor for the event "Merdeka Run." This event also becomes the media of cooperation in order to shape the position opinion for the FF Luxury Watch Store before the public. By being the sponsor for the annual event that has been held in order to commemorate the Independence Day of the Republic of Indonesia, the FF Luxury Watch Store has been indirectly considered to display high sense of nationalism to Indonesia since the Store is willing to take participation in the Independence Day Celebration.

\section{$>$ Holding Social Service in Nursing Homes}

Another pass strategy that the FF Luxury Watch Store has implemented is holding the social service in nursing homes. By holding the social service in nursing homes, positive opinion and impression will be indirectly created through the customer evaluation toward the Store. The customer evaluation in turn will result in the positive image, which will indirectly influence the customer loyalty. The presence of a company should be advantageous for the surrounding environment so that the surrounding community might be empowered by the activities that the company has held. Furthermore, the benefits from the presence of the company should be perceived by the surrounding community in order that the operational activities of the company might proceed smoothly without any disturbance or obstacle.

This kind of activity has become an intermediary between the company and the surrounding community. It becomes a commitment that a company should keep giving contributions to the surrounding community. Then, the benefits from the social activities that have been previously elaborated should be perceived by both the company and the surrounding company. By continuously contributing to the surrounding community, the products that the company has offered to the customers might be influenced. The customers will not only be viewed as offering the products but also taking participations in social activities. In the context of the Store, through the concrete movement that has been initiated, the customers gain the sense of taking participation into this concrete movement and believe that they also take participation in delivering changes to the surrounding community.

Due to the fact that the customers tend to view a company from the impression that has been established, and the benefits of the surrounding community has been accommodated, there is a mutual cooperation between the two parties. On the one hand, the strategy that the FF Luxury Watch Store has implemented is considered successful. On the other hand, there is an assumption that by shopping at the FF Luxury Store the customers will take participation in any charity events that the Store will hold.

\section{CONCLUSIONS}

After conducting the study, several conclusions might be drawn with regards to the management of marketing public relations strategy by the FF Luxury Watch Store to the customers in Jakarta. First of all, it is not already a taboo anymore that many watch stores have offered the luxurious watch products. As a result, the market competition has become increasingly intense and this situation has also taken place in the Province of Jakarta Special Capitol, which consist of five administrative area namely the Administrative City of North Jakarta, the Administrative City of West Jakarta, the Administrative City of East Jakarta, the Administrative City of South Jakarta, and the Administrative City of Central Jakarta. In these administrative areas, there are also many businessmen who offer the luxurious watches.

Within the study, it is found that the above situation has encouraged the customers to purchase the products that have been offered by the companies and this also applies to the FF Luxury Watch Store. From the aspect of strategy management, the FF Luxury Watch Store has been considered successful in shaping the customer loyalty to the products that have been offered. Within the management, three types of strategy have been implemented namely the push strategy, the pull strategy, and the pass strategy.

The FF Luxury Watch Store has implemented the push strategy by analysing the characteristics of the potential customers in-depth. This strategy is implemented in order to lobby the needs of the watch that the customers demand. After having identified the motif of the customers, the Store offers the alternatives by providing information about the strengths and the weaknesses of the watch that has been selected. With the presence of the information, the potentials customers might be curious and start to ask for further information about the price and the other items.

Then, The FF Luxury Watch Store has implemented the pull strategy by giving discounts to the customers and taking participation in numerous bazaars that have been related to the luxurious watch. This strategy is implemented in order to draw the interest of the customers especially by means of promotion. The promotions are usually held in October and November by giving $10 \%$ discounts for every purchase Rubber B strap for example. In addition, the Store has also promoted $1 \mathrm{x}$ free polish-service for every purchase in the Store.

Last but not the least, The FF Luxury Watch Store has implemented the pass strategy by holding fund-gathering events for the social activities. By holding this kind of social activities, the Store has been able to shape the positive influence before the public. Indeed, the FF Luxury Watch Store has frequently held the charity events such as gathering the fund for the orphans, becoming the sponsor for certain events such as Merdeka Run and celebrations of the Independent of the Republic of Indonesia, and also holding social service to the nursing homes through the distribution 
of food, rice, and other basic needs that might be needed most.

\section{REFERENCES}

[1]. Alifahmi, 1994, Marketing Public Relations Upaya Memenangkan melalui Pemasaran yang Komunikatif, Publikasi Lembaga Management FEUI, Jakarta.

[2]. Arifin Anwar, 2015, Paradigma Baru PR, Teori, Strategi, Dan Riset,Pustaka Indo, Jakarta.

[3]. Cutlip, 2007, Effective Public Relations, Kencana Pranada Media Group, Jakarta.

[4]. Eriyanto 2011- Analisis Isi Pengantar Metodologi untuk Penelitian Ilmu Komunikasi dan Ilmu-Ilmu sosial lainnya. Kencana Prenada Media Group. Jakarta.

[5]. Engel F James, 1990, Perilaku Konsumen, Bina Rupa Aksara, Jakarta.

[6]. Frank, 2003, Public Relations, Erlangga, Jakarta.

[7]. Fajar, 2009, Ilmu Komunikasi Teori \& Praktek Edisi Pertama: Graha Ilmu, Yogyakarta.

[8]. Griffin, 2003, Customer Loyalty: Menumbuhkan Dan Mempertahankan Pelanggan, Erlangga,. Jakarta.

[9]. Jamil Achmad, Enjang Pera Irawan, The Analysis of Lebak Smart City Application Based on Mobile in Improving Lebak Regency Government Service, International Journal of Sciences: Basic and Applied Research (IJSBAR) 2018) Volume 39, No 2

[10]. Kotler, 1994, Marketing Management: Analysis, Planning, Impelementation, Control, Prentice hall, New Jersey.

[11]. Kotler, 2002, Manajemen Pemasaran, Prehalindo, Jakarta.

[12]. Kotler, 2007, Manajemen Pemasaran, Jilid 2, Edisi 12, PT. Indeks, New Jersey.

[13]. Kriyantono, 2012, Teknik Praktis Riset Komunikasi:Kencana Prenada Media Group, Jakarta.

[14]. Kompasiana, https://www.kompasiana.com/anatasia/publicrelations-definisi-fungsi-tugas-dan-

[15]. tujuan_57f7a5f45fafbdef14d65536,

[16]. Lattimore, dan Otin Baskin, Suzette T. Heiman, Elizabeth L. Toth, 2010, Public Relations Profesi dan taktik, Salemba Humanika, Jakarta.

[17]. Miles dan Huberman, 2007- Analisis data kualitatif . Universitas Indonesia Press. Jakarta.

[18]. Mulyana Deddy, 2001, Ilmu Komunikasi Suatu Pengantar, Remaja Rosdakarya, Bandung.

[19]. Nugroho, 2003, Perilaku Konsumen, Konsep dan Implikasi untuk Strategi dan Penelitian Pemasaran: Prenada Media, Jakarta.

[20]. Qerja Empowering Your Career, diakses di https://www.qerja.com/journal/view/3734-pentingnyakegiatan-sosialre-bagi-perusahaan/)

[21]. Ruslan, 2001, Manajemen Humas dan Manajemen Komunikasi: PT. Raja Grafindo Persada, Jakarta.

[22]. Rosady, 2010, Manajemen PR \& Media Komunikasi: Rajawali Pers, Jakarta.
[23]. Rosadi, 2007, Manajemen Public Relations \& Komunikasi, Konsepsi, \& Aplikasi: PT. Raja Grafindo Persada, Jakarta.

[24]. Sigit, 2002, Pemasaran Praktis, edisi ketiga, BPFE, Yogyakarta.

[25]. Sumarwan, 2002, Perilaku Konsumen: Teori dan Penerapannya dalam Pemasaran: Ghalia Indonesia, Bogor.

[26]. Subiakto Utamie Vania, STRATEGI SOSIALISASI KEBIJAKAN PENDEREKAN OLEH SUKU DINAS PERHUBUNGAN JAKARTA BARAT, CoverAge: Journal of Strategic Communication Vol. 9, No. 2,

[27]. Thomas L. Harris, 1991, The Marketer's Guide to Public Relations, Son's Inc, New York,

[28]. Vardiansyah, 2004, Pengantar ilmu komunikasi: Ghalia, Bogor.

[29]. Wiwitan Tresna, Neni Yulianita. Strategi 'Marketing Public Relations' Perguruan Tinggi Islam Swasta: Peluang dan Tantangan di Era MEA, MediaTor Jurnal, Vol 10 (1), Juni 2017. 